Article

\title{
Factors Affecting e-Government Adoption by Dairy Farmers: A Case Study in the North-West of Spain
}

\author{
Alba Vázquez-López *(D) and Manuel Marey-Perez \\ Grupo de Investigación PROePLA, Escola Politécnica Superior, Universidad de Santiago de Compostela, \\ Campus Universitario s/n, 27002 Lugo, Spain; manuel.marey@usc.es \\ * Correspondence: albavazquez.lopez@usc.es
}

check for

updates

Citation: Vázquez-López, A.; Marey-Perez, M. Factors Affecting e-Government Adoption by Dairy Farmers: A Case Study in the North-West of Spain. Future Internet 2021, 13, 206. https://doi.org/ $10.3390 /$ fi13080206

Received: 22 July 2021

Accepted: 1 August 2021

Published: 5 August 2021

Publisher's Note: MDPI stays neutral with regard to jurisdictional claims in published maps and institutional affiliations.

Copyright: (c) 2021 by the authors. Licensee MDPI, Basel, Switzerland. This article is an open access article distributed under the terms and conditions of the Creative Commons Attribution (CC BY) license (https:/ / creativecommons.org/licenses/by/ $4.0 /)$.

\begin{abstract}
With the objective of assessing the farmers' situation regarding the use of the ICT and their relations with the electronic government, a case study consisting in the realization of 34 faceto-face surveys was conducted between February and March 2020 in dairy farms in the region of Galicia (Spain). The sample was selected according to one of the most important online journals in the farming sector at a national level. From the census, we chose those farms considered most representative taking into account the main criteria: the level of PAC (Common Agrarian Politics) subsidies and milk production (litres/cow and year). The results show that the majority of the farmers used the internet, but on many an occasion, they were discontented in relation to the poor connection quality in their farms. In regard to the use of the electronic government for procedures related to their farms, many of them were able to perform them through the government website; however, there were procedures which the users defined as "complex" and which had to be outsourced to authorised entities. The results also show that the farmers do want to employ the e-government, mainly because of the time and cost saving; however, the current web pages do not meet the users' expectations. Finally, this situation, applied to a region placed among the 10 most productive regions of milk, is comparable to what happens in other regions.
\end{abstract}

Keywords: ICT; dairy farms; e-government; digital divide; connectivity

\section{Introduction}

Due to the great importance that the ICT (Information and Communication Technologies) have acquired nowadays, [1] acknowledges and underlines the dependence on digital media that exists in our daily lives, both in the professional and personal spheres, as well as in the public and private sectors [2]. This situation, set in the public sphere, implies a restructuring of the government through new ways of communication and service features employing the ICT [3-5]. Besides, nowadays, according to what has been displayed in the new European law of administrative procedures [6], every legal entity must communicate with the Administration telematically, which directly implies dairy farmers, who are the main focus of the present paper.

In spite of what has been stated, there are still problems related to the lack of connectivity and inclusion which lead to a new type of inequality called "digital divide" [7-12], which affects mainly the inhabitants of rural areas due to the lack connection infrastructures [11-21]. These are facing an unsolved problem [7,10] which is becoming bigger, as the lack of connectivity generates issues associated with the lack of digital abilities and knowledge which increase due to this absence of opportunities to improve [22-24].

Focusing on dairy farms as the main topic of our research, this digital divide is a great obstacle for their survival and development since, as demonstrated in studies carried out by [25], the use of the ICT is related to income growth. Besides, added to this situation, we have to bear in mind that in the last few years, they have suffered great changes aimed at an increase in the size of the farms [26-28] together with an 
increase in the production of each animal [29-31]. In this context, we can observe a clear tendency to "smart farms" [32-34], which allow this sector to adjust to the new market demands, oriented towards the improvement of the product quality at the minimum possible cost [35]. Here, ICTs come into play in farms, since they have proved to be a method for reducing risks and uncertainties, thus improving decision-making processes in every field [36-38]. This tendency to bigger farms with a greater performance finds itself against another tendency which is becoming increasingly popular and which aims to transform industrial farms into organic and sustainable, family-size farms, within the Green Deal framework [39]. Related to this terminology, studies performed in New Zealand by [40] show new organization methods for dairy farms, conceiving agro-ecological parks as a viable and integrative method for all involved parties (environment, farmers, animals and business). In researches carried out by [41] in Alpine dairy production areas about the assessment of the environmental footprint, it is shown how different types of production live together, from the more traditional and extensive farms to the intensive ones.

In terms of the specific field of the relation existing between farms and the corresponding administrative authorities, it is worth mentioning that, in many cases, it is burdened by the inefficient use of the ICT, since the low-income population find themselves at a disadvantage in terms of connectivity and, by extension, inclusion of the new technologies in their activity $[11,12,42]$. In the last few years, many studies based on different technology acceptance models by the users have been conducted, mainly in relation to the e-government [43-51]. In studies performed by [46] based on the technology acceptance model (TAM), differences are observed between the determining factors for the adoption of technology in urban and rural areas, in the latter essential for the users being the ease of use, the perceived usefulness, the perceived security, the subjective norm and the inhibiting factor. In other studies also based on TAM, such as those conducted by [47], trust is shown as the main factor to obtain citizen participation in the e-government. Based on the unified theory of acceptance and use of technology (UTAUT), [48] take a step forward, prioritising trust in politics for the adoption. Other research, such as that directed by [44], addresses the habit (which springs up after implementation) and the facilitating conditions as strong promoters of electronic participation. [50] go even further: based on UTAUT, they apply in their studies the unified model of electronic government adoption (UMEGA), which reflects four essential factors for the adoption of technology: the provision of conditions to facilitate electronic government, the extent of the risk, the nature of the perceived quality of the service and the trust in the government. [52] in their research about technology acceptance by German farmers show that the key components are the ease of use and the usefulness perceived by these users.

From the point of view of the use of the ICT in this sector, [53] in their studies carried out in Ireland about the use of the new technologies in farms point out that their use in the context of agriculture businesses continues to be fairly low and they are more likely to be employed in bigger farms, in such a manner that three types of farms may be distinguished: farms which lack a computer, farms which have and use a computer and farms which have but do not use a computer for agricultural commercial purposes. At this point, precision agriculture comes into play [54,55]. Ref. [55], in surveys conducted in Australia on dairy producers and suppliers about the relation between herd size, the current adoption of precision technology and the perception of the future of precision technologies, show that the bigger the farms are, the more they adopt more specific precision technologies. To this contribution, we have to add the fact that other studies, such as those performed by [56] also about this user profile, show that their main concern is to have all relevant data related to their animals available through a central database, which makes clear the necessity of developing a data management integrated tool.

The objective of this study is to know the dairy farmers' point of view on the public administration web pages, in terms of ease of use and the time needed to carry out procedures. More specifically, the degree of resolution which these web sites offer is analysed, and whether the in-person fulfilment of procedures is still necessary. With 
that, we analyse the degree of acceptance, the shortcomings and the issues detected by these users.

\section{Materials and Methods}

\subsection{Area of Study}

Galicia is a European region (NUT 2) located in the northwest of the Iberian Peninsula (Figure 1). It is an area closely connected to rural activities since, in terms of dairy production, there are 6695 farms (FEGA, 2019), which are distributed as shown in Figure 2. It can be noticed that the northern half of the region gathers the vast majority of dairy farms, whereas there is a great absence of farms in the southern areas. Besides, as shown in researches led by $[57,58]$, this region provides more than $38 \%$ of the total Spanish dairy production and approximately $1.5 \%$ of the dairy production of EU-27, holding 8th position in the most productive regions for milk in Europe (Eurostat, 2017).

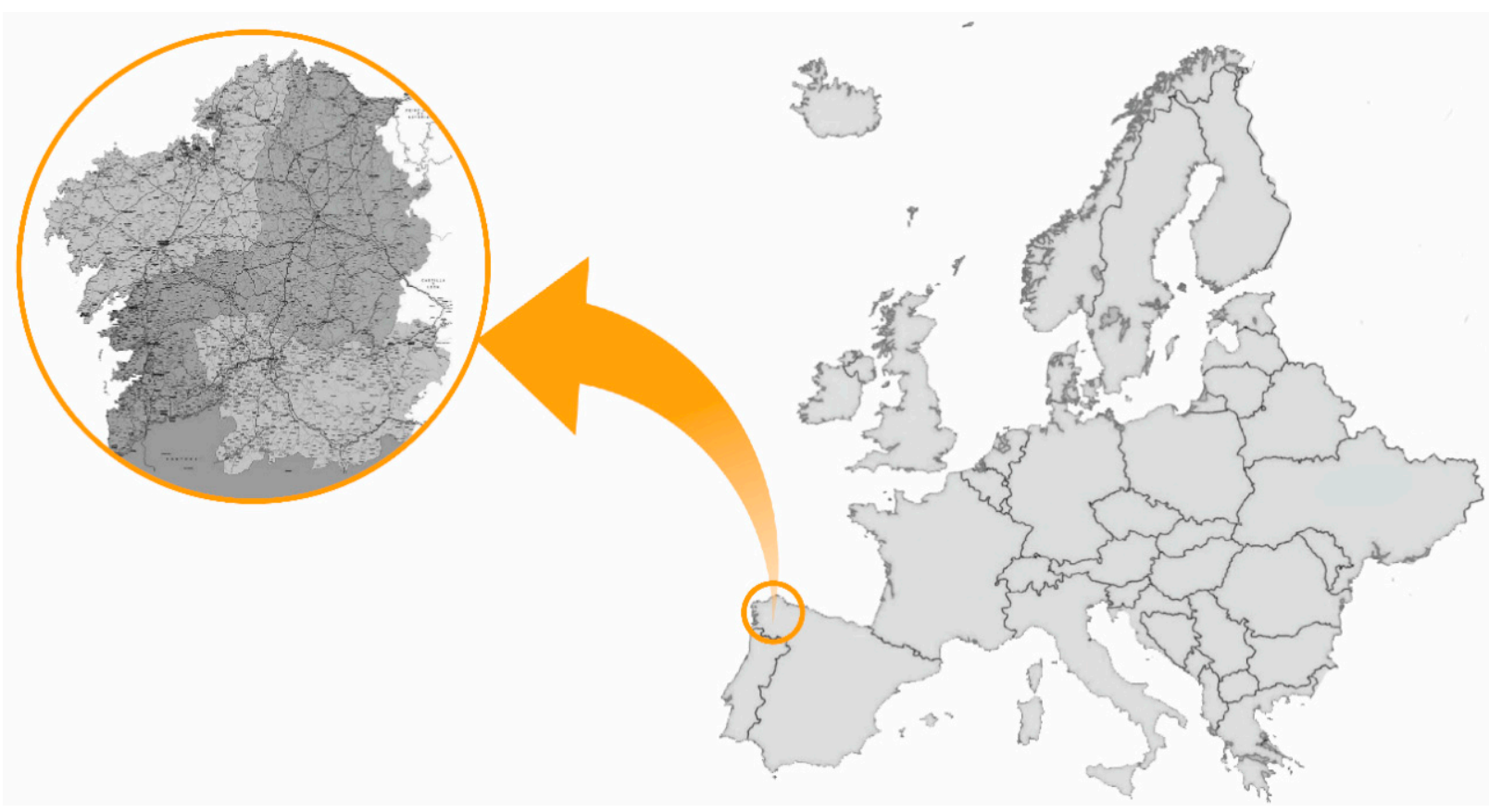

Figure 1. Location of Galicia.
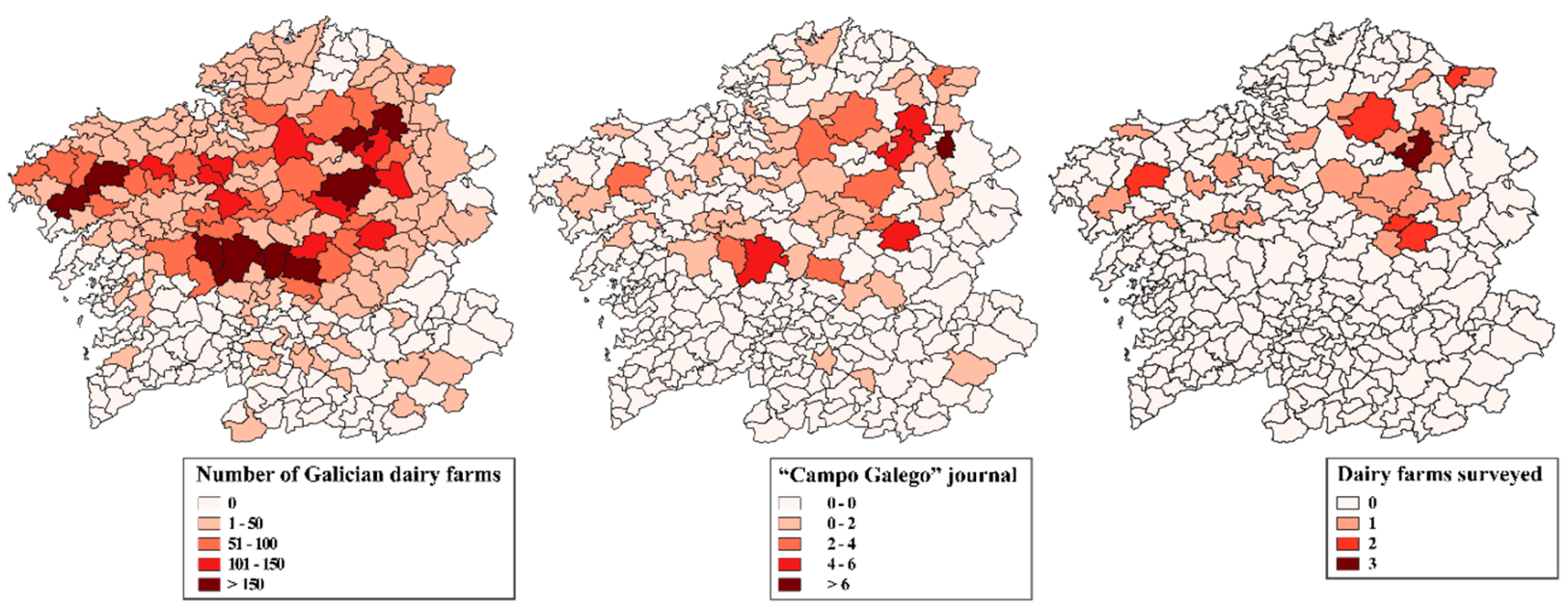

Figure 2. Galician dairy farms. 
The year 2015 meant a turning point in the business structure of dairy farms since, with the suppression of the milk quotas which had been present for 30 years in Europe [59], the production volume per farm increased at the same time that the price per litre of milk lowered [60-66]. This brought about important changes so as to adapt to these new demands from the market. As a result of this situation, the number of farms has been reduced [27] and this has given way to the intensification of farms in terms of size and production per animal [26,67]. In this scenario, new developments and technologies appeared to ease the work in the farms and to increase the productivity, as is the case of the AMS (Automatic Milking System) [68,69]. Besides, according to [57] in their studies, it has also brought about a clear tendency to the association of farms into cooperatives in order to be able to meet the demands of the market.

\subsection{Methods}

Surveys fulfilled through face-to-face interviews have been very commonly employed since they generate a great amount of data [70]. In the specific field of dairy farms, it is worth mentioning surveys led by [71-74].

The documentary basis employed for the correct identification of dairy farms was a leading magazine at national level called "Campo Galego" (http:/ / www.campogalego. $\mathrm{com} / \mathrm{es} /$, accessed on 4 July 2021), which performs interviews with the most highlighted Galician farms in terms of innovation, genetic selection and intensification. Afterwards, these data were completed with the database from Africor (Asociación Frisona de Control Oficial de Rendimento, http: / /www.sfricorlugo.com/, accessed on 4 July 2021) and FEGA (Fondo Español de Garantía Agraria, http:/ / www.fega.es/, accessed on 4 July 2021).

Speaking of the selection of variables for the sample choice, authors such as [72] used different variables, namely: family income, which should come from dairy production (at least half of the total amount); and the sale of milk or dairy products. Other authors such as [75] employed, as variables of selection, the belonging to the 12 Irish advisory regions, which were part of an organism called "Teagasc". Others such as [25] used a random sample, statistically representative, from the FADN (Farm Accountancy Data Network) database. In the case of the present paper, we have considered the variables shown in Figure 3, based on "Campo Galego's" database, with a total of 101 interviewed farms whose location is detailed in Figure 2.

The two variables described in Figure 3 were selected as being essential from the point of view of the prosperity of the farms in the future, since the PAC subsidies focus on the realization of improvements to achieve the objectives of the market; therefore, the greater their extent, the greater the probability of success; on the other hand, the production volume influences the level of competitiveness of the farms under increasingly demanding market conditions, aimed at reducing costs and increasing productivity.

Several interviews with four types of questions were conducted, making a total of 27 questions. In the case of users who employed the internet in their daily lives, a maximum of 23 questions would be answered, whereas in the case of users who presented difficulties, they would answer a maximum of 13 questions (Figure 4). 


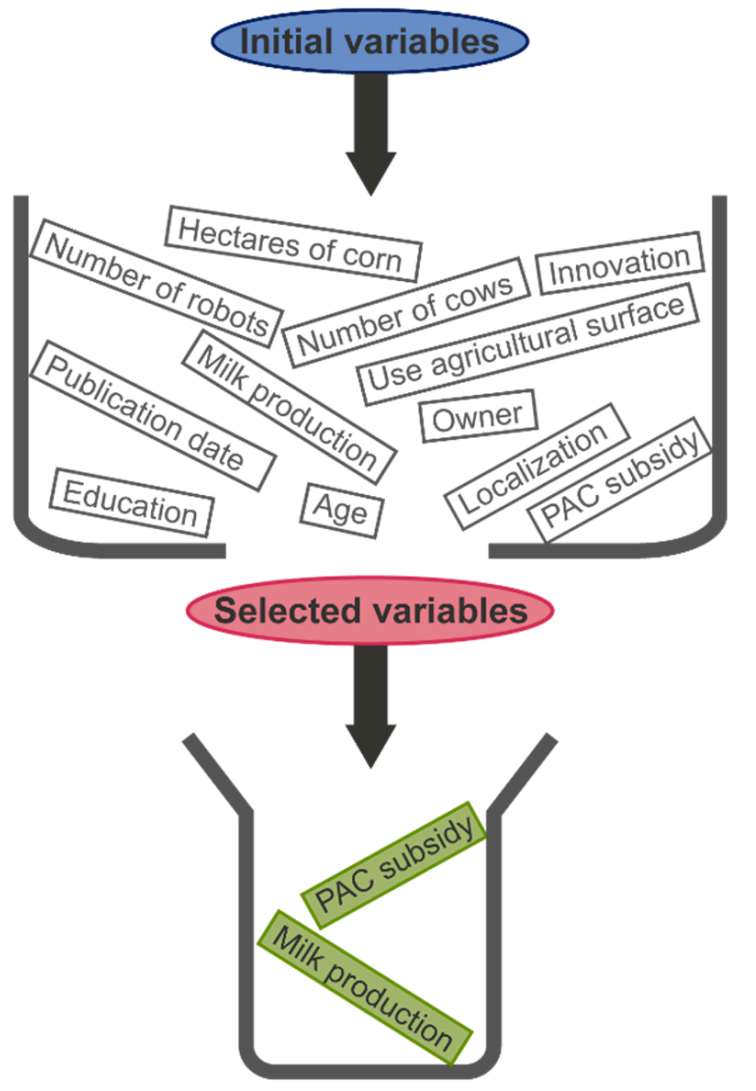

Figure 3. Process of Variables Selection.

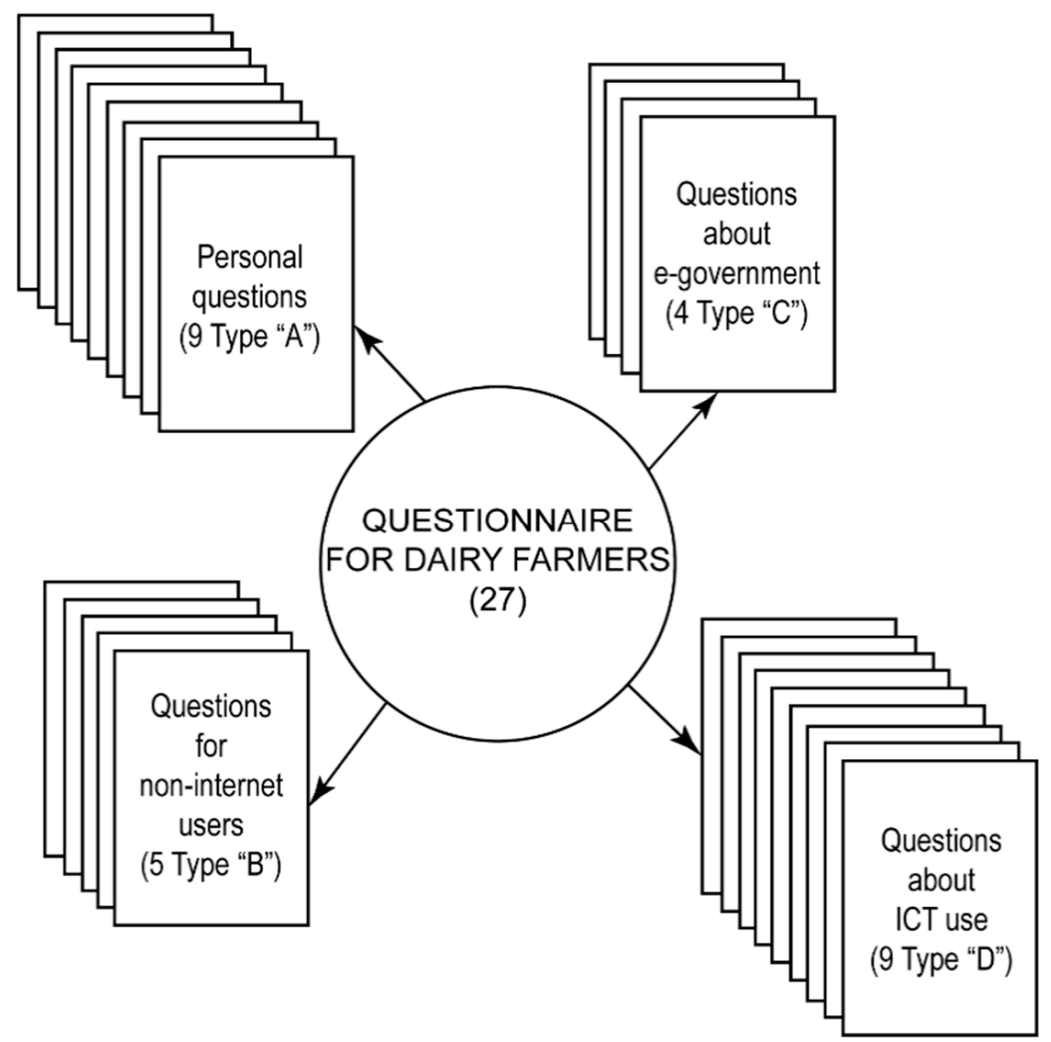

Figure 4. Questionnaire. Typology and Number of Questions. 
Figure 5 shows the main characteristics of a total of 19 questions, which are the ones that will be shown in the section "Results". The questions presented are divided in three branches (Questions Type A, C and D). Within each section, there are different possibilities of question codification: binary, ordinal and nominal. The binary questions only had two possible answers (Yes $=1 ; \mathrm{No}=0)$, the ordinal questions gave the interviewee several options (e.g., WhatsApp = 1; Bank $=2$; E-mail $=3$; Others $=4$; Not applicable $=5$ ), and the nominal questions had a free answer. The method used for carrying out the surveys, as pointed out before, was employed in this field by other authors such as [72-77].

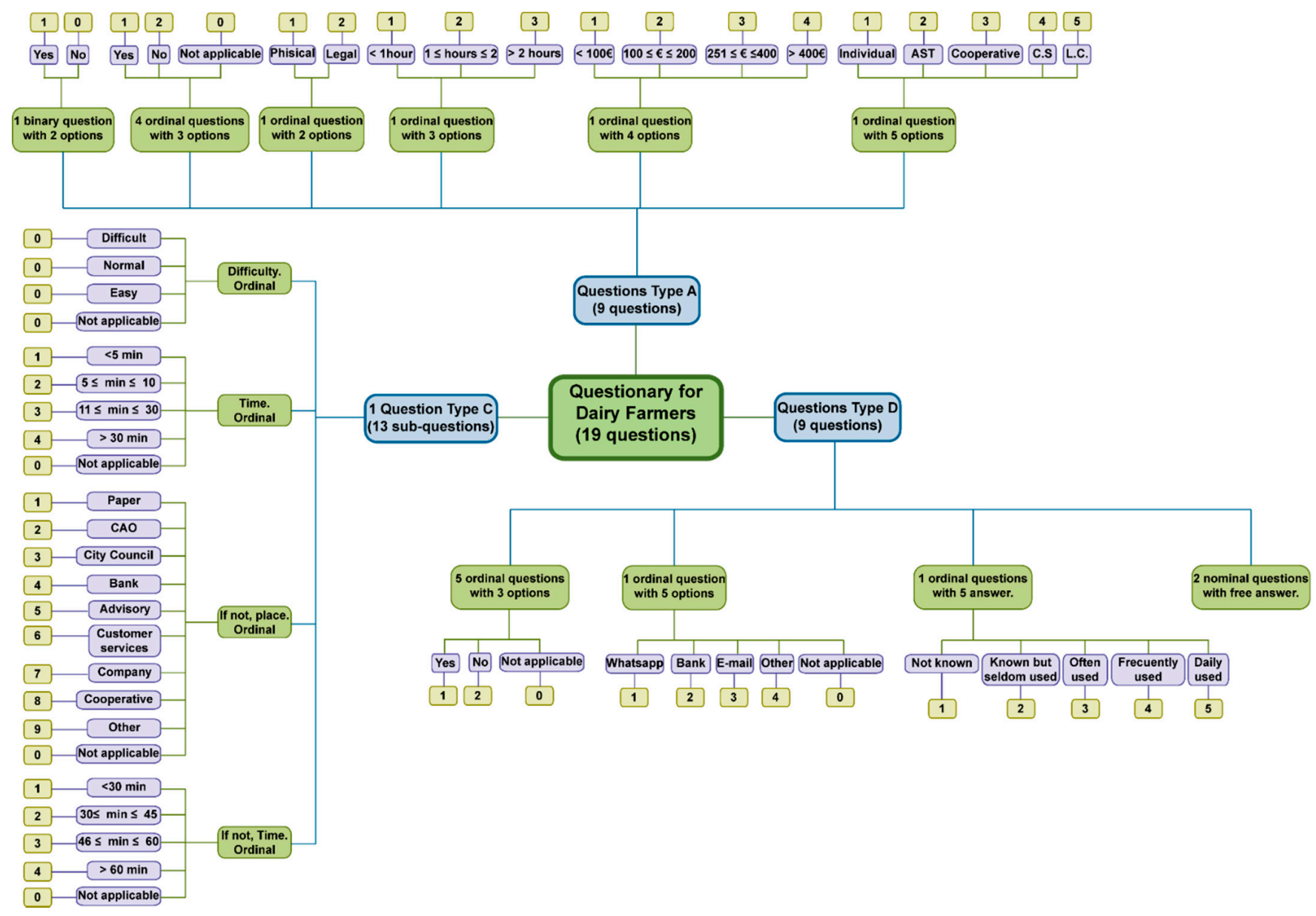

Figure 5. Typology of Questions. Codification.

For the realization of the case study, we chose the 34 dairy farms which best adjusted to the two criteria selected (Figure 2). The definite questionnaire began in mid-February 2020 and ended in mid-March 2020. The first stage consisted of a telephonic interview, in which the owner was asked whether s/he was willing to participate in the research. Once confirmed, a personal interview was arranged.

Several statistical analyses were performed in order to assess the possible differences between groups. First of all, the most representative variable "production" (measured in litres/cow) underwent a normality analysis employing the Kolmogorov-Smirnov test [78]. The result showed that it was a non-normal variable; hence, non-parametric contrasts were done, more specifically, the Mann-Whitney U test [79], with the objective of knowing which variables could be representative in terms of the use of the internet. In order to do that, the main variables which had been taken into account for this study were also used as test variables, such as age, number of cows, production, Agrarian Land Use (ALU) and CAP subsidies; and as a grouping variable, the use of the internet (employing two groups: 
one of them being the farmers who did use the internet and the other those who did not use it or had difficulties using it).

\section{Results}

The 30 surveyed farms were of the intensive type, since one of our main selection variables was "litres/lactation". In spite of that, they presented very different characteristics, from small-size farms focused on the field of animal genetics, to larger farms which received more CAP (Common Agrarian Policy) grants and whose main priority was innovation and cattle management.

\subsection{Information of Personal Character and Aptitudes towards Technological Innovations}

The results of the questions related to the farmers' personal characteristics were classified as "Type A", and are detailed in Figure 6. It is worth mentioning that the surveyed people belonged to business clusters of individual and cooperative types.

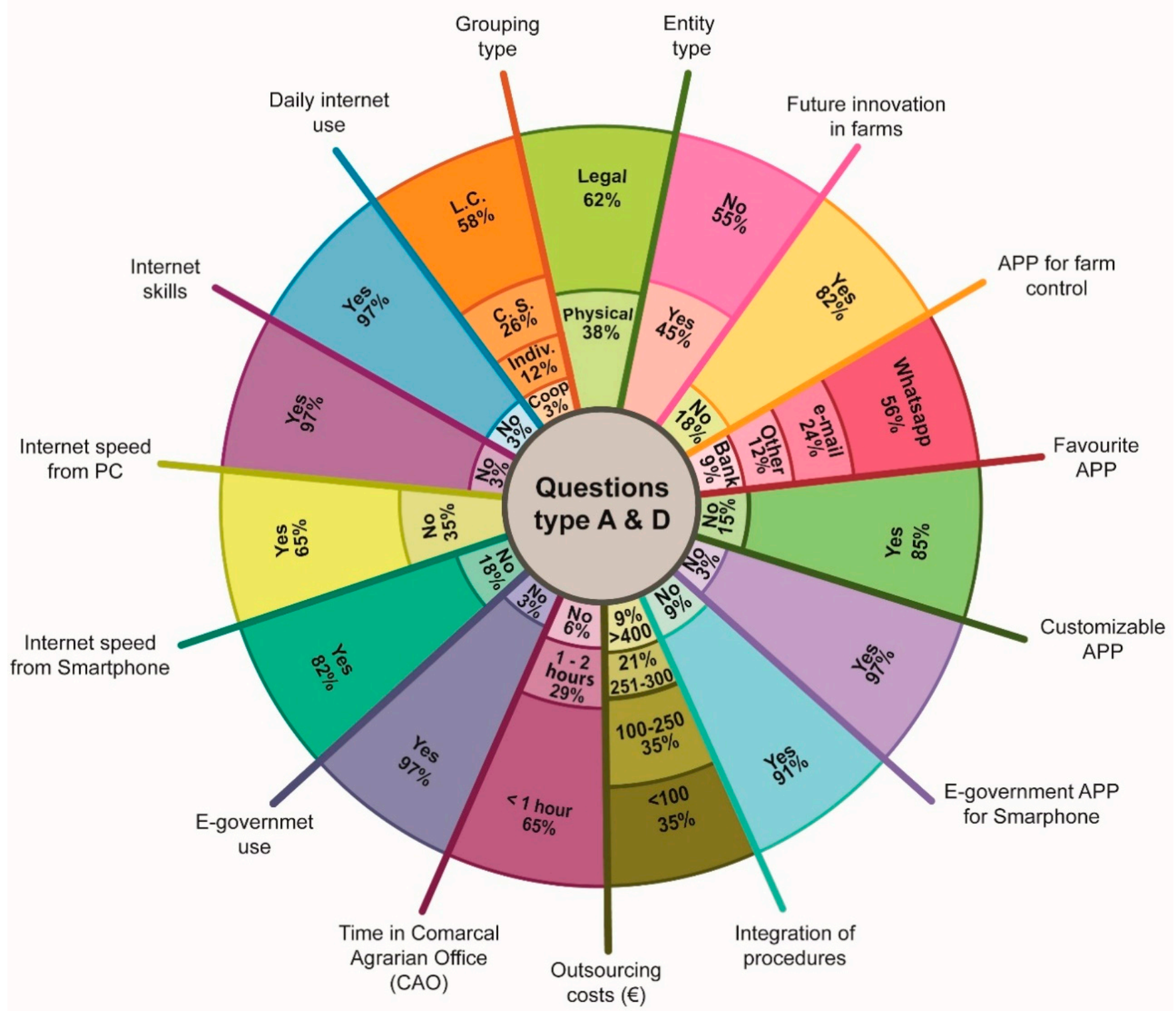

Figure 6. Personal Questions and Aptitudes towards ICT. Percentage of Answers.

In terms of the use of the internet, $97 \%$ of the users declared that they employed it, apart from being proficient with the new technologies. Concerning the connection quality, 
22 out of the 34 interviewed farms affirmed that they had enough connection quality to carry out procedures, despite the fact that the connection speed never got close to the $30 \mathrm{Mbps}$ established as the minimum connection speed by the strategy Europe 2020 (new agenda for growth and employment in the second half of the XXI century). A figure of $35 \%$ of the surveyed users declared that they had very poor conditions for internet use. The smartphone connection was better, since 28 subjects were satisfied with this service.

When they were asked about the use of the electronic headquarters of the public administration, $97 \%$ declared that they used it, despite the fact that they still had to visit the Regional Agrarian Offices (RAO) in order to carry out procedures. Concerning the estimated time employed in the RAOs, 22 farmers declared that they usually needed less than an hour. They were also asked about outsourcing procedures to authorised entities in terms of costs, to which 12 of them answered that it meant less than $€ 100$ per month, another 12 that it was between $€ 100$ and $€ 250,7$ that the cost was between $€ 251$ and $€ 400$; and a minority of the interviewed users ( 3 people) affirmed that it was over $€ 400$.

The questions related to the aptitudes towards technological innovations were named "Type D", whose results are also shown in Figure 6. In this section, 31 farmers declared that it was necessary to integrate all the procedures of the public administration into a single application. Besides, 33 of them felt assured that a smartphone application would be very useful. Twenty-nine considered it important to generate a more personalised application which differentiated the type of activity, that is, dairy cattle (currently, there is no distinction of the type of farm activity); 19 affirmed that the most useful application in their everyday life concerning problem-solving was WhatsApp; 8 mentioned email; 3 the electronic bank; and 4 highlighted applications related to weather forecasting and farm control. In terms of technologies or applications for the control of the farm, $82 \%$ of the interviewees declared that they owned one. Of those who still had not implemented one, 5 said that they wanted to implement farm innovations in the near future.

Regarding the need of a government application for smartphones, they were asked about the improvements they believed it should have. A figure of $39 \%$ considered it was essential to integrate all data in a single APP, $15 \%$ saw the need to create an agile and easy-to-use tool, another $15 \%$ mentioned the need of personalisation. On the other hand, $6 \%$ claimed to be satisfied with the current tools and $27 \%$ did not answer.

The use and knowledge of the most popular APPs is shown by percentages in Figure 7 (which also belongs to group " $\mathrm{D}$ "), where each colour (as shown in the legend) represents a degree of knowledge and use, which appears represented on the $X$ axis with their corresponding degrees of knowledge and use. In this manner, as shown in the figure, the most used APPs were: Whatsapp, with a total of 28 users who used it on a daily basis; Google, with 26 of the surveyed people who also claimed to use it every day; and email, which was also used daily by 24 of the interviewed users. A smaller group declared that they used other applications on a daily basis such as: social media, used by 28 farmers; electronic banking, employed by 15; online shopping, used only by 5 interviewees.

The most highlighted APP is, without a doubt, Google, which is known by all the users and is employed by them to a greater or lesser extent, depending on their necessities. Other applications such as WhatsApp, email and electronic banking, were known and used in different proportions by $97 \%$ of the users. The least known applications were social media and those related to online shopping, 6 users stating that they had never used them. 


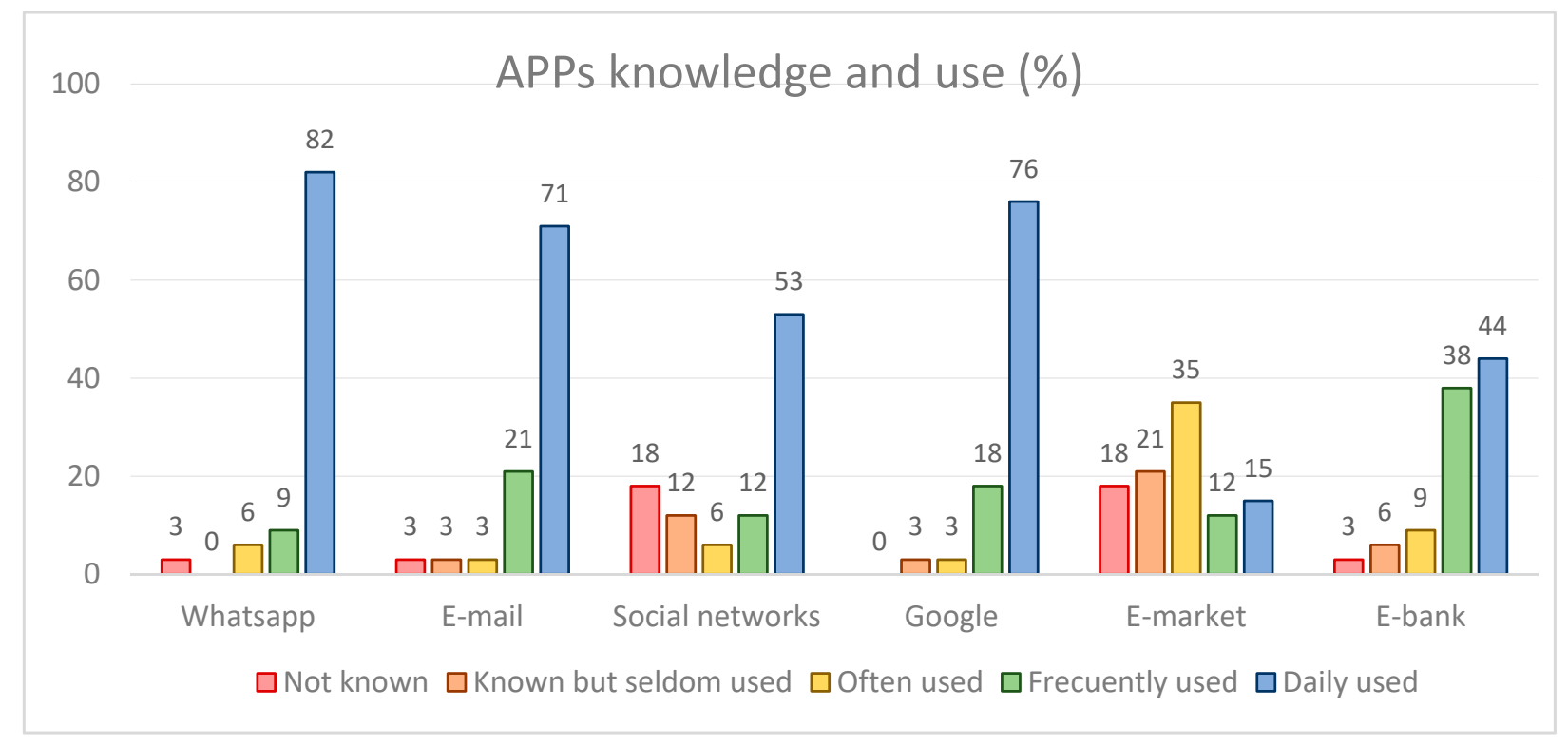

Figure 7. Degree of Knowledge and Use of the APPs.

\subsection{Information about the Fulfilment of Procedures through the Electronic Headquarters of the Administration}

The results concerning the fulfilment of procedures on the different webs offered by the public administration to the sector of agriculture and livestock farming are shown in Table 1.

Table 1. Type C Questions. Percentage of Answers.

\begin{tabular}{|c|c|c|c|c|c|c|c|c|c|}
\hline \multicolumn{10}{|c|}{ Questions Tipe C } \\
\hline \multirow{2}{*}{ Procedures e-Government } & \multicolumn{2}{|c|}{ Use } & \multicolumn{3}{|c|}{ Affimative. Difficulty } & \multicolumn{4}{|c|}{ Affirmative. Time } \\
\hline & Yes & No & Difficult & Normal & Easy & $<5 \min$ & $5 \leq \min \leq \mathbf{1 0}$ & $\mathbf{1 1} \leq \min \leq \mathbf{3 0}$ & $>30$ \\
\hline 1. Consultation of farm book & $62 \%$ & $38 \%$ & $0 \%$ & $29 \%$ & $71 \%$ & $76 \%$ & $19 \%$ & $5 \%$ & $0 \%$ \\
\hline 2. Consultation of census & $91 \%$ & $6 \%$ & $0 \%$ & $22 \%$ & $78 \%$ & $81 \%$ & $13 \%$ & $6 \%$ & $0 \%$ \\
\hline 3. Consultation of cattle movements & $82 \%$ & $18 \%$ & $0 \%$ & $18 \%$ & $82 \%$ & $82 \%$ & $14 \%$ & $4 \%$ & $0 \%$ \\
\hline 4. Consultation of registered procedures & $79 \%$ & $21 \%$ & $4 \%$ & $22 \%$ & $74 \%$ & $78 \%$ & $19 \%$ & $4 \%$ & $0 \%$ \\
\hline 5. Change of personal data & $18 \%$ & $82 \%$ & $17 \%$ & $0 \%$ & $83 \%$ & $100 \%$ & $0 \%$ & $0 \%$ & $0 \%$ \\
\hline 6. Birth registration & $94 \%$ & $6 \%$ & $0 \%$ & $9 \%$ & $91 \%$ & $75 \%$ & $13 \%$ & $13 \%$ & $0 \%$ \\
\hline 7. Duplication of eartags & $88 \%$ & $12 \%$ & $3 \%$ & $17 \%$ & $80 \%$ & $53 \%$ & $30 \%$ & $17 \%$ & $0 \%$ \\
\hline 8. Declaration of movement & $91 \%$ & $9 \%$ & $0 \%$ & $10 \%$ & $90 \%$ & $71 \%$ & $26 \%$ & $3 \%$ & $0 \%$ \\
\hline 9. Request of regular guide & $50 \%$ & $50 \%$ & $12 \%$ & $24 \%$ & $65 \%$ & $41 \%$ & $41 \%$ & $6 \%$ & $12 \%$ \\
\hline 10. Request of autoguide & $50 \%$ & $50 \%$ & $12 \%$ & $35 \%$ & $53 \%$ & $47 \%$ & $41 \%$ & $6 \%$ & $6 \%$ \\
\hline 11. Request of environmental licenses & $38 \%$ & $62 \%$ & $0 \%$ & $31 \%$ & $69 \%$ & $54 \%$ & $38 \%$ & $8 \%$ & $0 \%$ \\
\hline 12. CAP grants & $9 \%$ & $91 \%$ & $0 \%$ & $67 \%$ & $33 \%$ & $33 \%$ & $0 \%$ & $0 \%$ & $67 \%$ \\
\hline 13. Obtention of official forms & $26 \%$ & $74 \%$ & $11 \%$ & $44 \%$ & $44 \%$ & $33 \%$ & $33 \%$ & $11 \%$ & $22 \%$ \\
\hline
\end{tabular}

According to the users of the web site for livestock farming, the procedures were usually easy and had an average fulfilment time of $5 \mathrm{~min}$. In the case of the farm book, 13 of the interviewees claimed to have one. There are some procedures where it can be observed that the users still did not use this tool to carry them out, as in the case of census consultation, where $6 \%$ did not do it; the cattle movements consultation, where $18 \%$ claimed that they did not to perform it; or the registered procedures consultation, with $21 \%$ of the surveyed users not doing it. In these cases, the users admitted that it was enough for them to have it on paper.

There is a procedure which is very uncommon or even unknown by many users: the change of personal data through the web site; only 6 users had ever done it.

In terms of birth registration procedures, eartags duplication and movement declarations, a very reduced group of users (6-12\%) still did it on paper. Concerning regular guides and autoguides request, only half of the users fulfilled this procedure through the web portal. 
The situation was very different when we asked about the request for environmental licenses (Ministerio de Medioambiente y Sostenibilidad) since, in this case, fewer than half of the users ( 13 users) chose to do it through the web. To a greater extent, the same happened with the public economic grants (CAP), where only 3 of the interviewed users had ever consulted something.

Finally, concerning the obtainment of official forms, 25 interviewees did not fulfil them through the web site, but they outsourced them to an advisory. Only 9 of the surveyed people affirmed to have ever done this procedure.

In terms of the procedures that some users still did in person, some questions were asked oriented towards the place of fulfilment of these and the time employed for this purpose (Table 2). In the case of eartags duplication, $12 \%$ of the users still did it through the telephone service or in an RAO. Concerning the request of guides and autoguides, of half of the interviewees who did not do them, 9 of them did not perform them since they stated that they did not need them. Of those who fulfilled this in-person procedure, $31 \%$ did it in an RAO, $6 \%$ on paper and another $6 \%$ with the animal dealer. Speaking about the environmental licenses, of the users who did not fulfil them through the web portal, 6 claimed that they did not need them, and of those who actually needed them, 7 used the telephone customer service, 3 went to the city council, 2 had third-party assistance and 1 went to the RAO.

For the public economic subsidies, 20 farmers claimed that they performed this procedure in a banking entity, 6 in an advisory, 2 in an authorised entity and 1 using cooperatives. The time employed by the majority of the surveyed farmers was more than one hour. For the obtainment of official forms, more than half of the users who did not fulfil them through web site claimed that they had never needed them, and the rest outsourced them to an advisory.

In general, it has been observed that the farm size had a great influence upon the quality of the answers since, the larger the farm, the more need of performing large-scale daily procedures. As a consequence, these presented more knowledge of the functioning of the applications and more capacity for problem detection.

Table 2. Type C Questions. Place where they fulfil them and time they need.

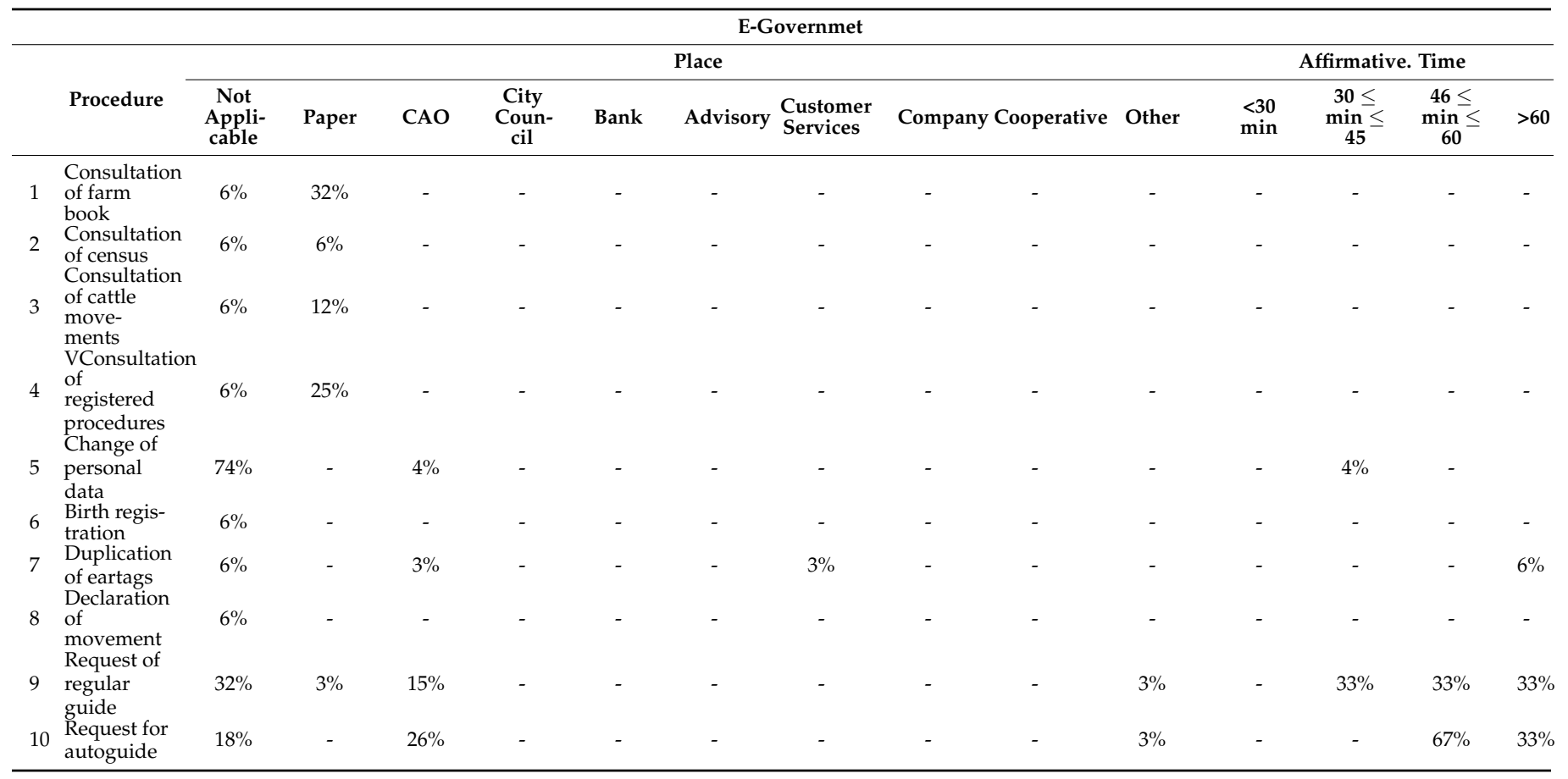


Table 2. Cont.

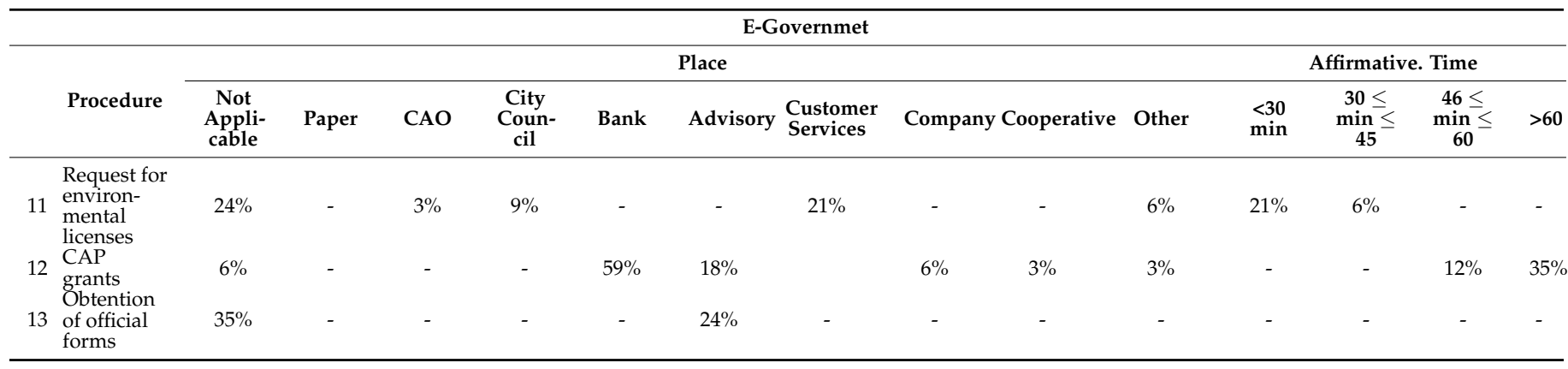

\subsection{Group Analysis}

Table 3 shows the results of the normality test. We can observe that the variable "production" does not fulfil the normality hypothesis.

Table 3. Kolmogorov-Smirnov test.

\begin{tabular}{lll}
\hline & & Production \\
\hline $\mathrm{N}$ & & 34 \\
Normal parameters & Average & 38.6176 \\
Test statistic & Standard deviation & 3.52493 \\
$p$ & & 0.217 \\
\hline
\end{tabular}

After verifying that our variable was non-normal, we proceeded to the fulfilment of a non-parametric test, choosing the Mann-Whitney U test. As can be observed in Table 4, age is the only variable which can be considered meaningful regarding the use of the internet in farms, $p=0.043$; this means that the groups do show differences, in spite of the fact that they are small. In the rest of the analysed variables, we do not find differences between groups.

Table 4. Mann-Whitney U test.

\begin{tabular}{cccccc}
\hline & Age & Cows & Production & ALU & Grant \\
\hline Mann-Whitney U & 66,500 & 92,500 & 104,000 & 106,000 & 116,000 \\
$p$ & 0.043 & 0.298 & 0.540 & 0.596 & 0.880 \\
\hline
\end{tabular}

It is important to take into account that since the groups are not very large, the results may be conditioned. Therefore, the size of the cattle, which observationally seemed a predictive factor of the use of the e-government, eventually had a value of $p>0.05$; therefore, it was not meaningful.

\section{Discussion}

In the same line as authors such as $[52,53,56,67,71,73,74,76,80]$, the methodology employed in the present paper has allowed us to know the characteristics of dairy farms in relation to the knowledge and use of the ICT, which are presented as fundamental tools in this sector. The results show the existence of different types of users, since the surveyed farmers presented different features from farm type to age range.

Beginning with the discussion of the results relative to the connectivity in the farms, we find that the ICT are used at all levels in our daily lives, becoming essential for communication, education, entertainment or online shopping, among others [81]. Speaking of connectivity, the results evince that the connections in the rural world are still deficient, as shown in studies performed by authors such as [22-24]. However, in our study, a better service has been observed for smartphone connection than for PCs. Connections from 
computers never reached what has been established in the objectives of the European Union, even though the farmers were happy if the connection speed, despite the fact that it was inferior to the established one, was enough to perform their usual procedures.

Concerning the results obtained in relation to the importance and the degree of effectiveness of the electronic headquarters of the public administration, we find that the strategy Europe 2020 establishes as one of its main objectives the increase of the services offered by the new technologies $[7,9,82]$, giving room to a redevelopment of the administration through new communication methods and provision of services using the ICT [3]. This situation directly affects dairy farmers, since they are experiencing important changes in the way of fulfilling procedures. If in the past they could solve these procedures on paper and with the assistance of the RAO, now, with the massive implementation of the new technologies in every sector, they have the obligation to do all the administrationrelated procedures through different web pages, which provokes, in the majority of cases, as we were able to confirm in the results of the survey, lack of knowledge and uncertainty, which are translated into outsourcing, calls to the telephone customer service or visits to Regional Agrarian Offices. In this area, as shown by researches led by [24] in Boorowa and Crookwell in New South Wales (Australia), rural inhabitants have a clear disadvantage concerning the implementation of the electronic government, since they experience the online sites differently due to the poor connection and the privatization of these services.

To these facts we have to add that, even though some studies performed in Spain by [83] show that the online sites of the public administration are key tools for the diffusion of information, the results obtained in the present paper demonstrate that there are great deficiencies in these web pages, considering that we can observe an important dispersion of information in different web addresses which generates rejection when it comes to using them and results in an inefficient performance on the users' part, who have to resort to other options so as to solve their problems. These results are closely related to those obtained by [50] based on UTAUT and UMEGA, where it is observed that the nature of the perceived quality of the service and, in addition, the trust in the government are fundamental to determine the intention of use. This situation demonstrates that there are still critical success factors and that the current models do not meet the citizens' needs and expectations [84]. We also have to take into account the poor connection conditions, which hamper the inclusion of the new technologies in their activity [42].

The results of this study also show that one of the farmers' current concerns is to have all the information relative to their animals integrated in a single application, which should be more efficient in terms of data fulfilment and the ratio of time required to carry out procedures. These results coincide with those obtained by [56] in Austria from dairy farmers, where we can observe these users' concerns for having all the data referring to their animals in a single database.

In relation to farm management, it is worth taking into account that the number of farms has diminished at the same time as the number of animals and the performance per animal have increased [26,67]. This situation has brought about, as seen in previous sections, new types of business groups which, besides, due to the complexity related to the increase in their size and the market demands, are commonly associated into cooperatives [57]. These are useful in terms of solving many daily procedures, such as public economic subsidies or other questions related to their sector.

In relation to the foregoing, in the results, we can see how many procedures are still fulfilled in person or by outsourcing them to authorised entities. This situation shows again that the current tools do not meet the users' needs and expectations, and because of that, as demonstrated in studies performed by [85] in New Zealand, for a correct implementation, simple and flexible tools which take into account the users' needs and which allow the integration with other tools would be necessary. Moreover, studies carried out by [46] in China based on the technology acceptance model, TAM, show ease of use and perceived usefulness as some of the key factors for the acceptance of technology by the rural citizens. The last result is closely related to those obtained in this study, as many of the interviewees 
emphasised the necessity of a nimble and logical tool that would prevent them from commuting unnecessarily.

Related to the farmers' attitude towards the ICT, the results show that the vast majority of the surveyed people used the several options which they offer, even though it is also true that, as shown by [77] in their studies on 817 German farmers, there are still factors which hinder the process of implementation of the ICT, such as age, education or the size of the farm. In terms of age, it has been also observed in our study as a meaningful variable regarding the use of the new technologies. Besides, regarding the size of the farm, our observations show that the bigger the farm is, the better use of the ICT the farmers have $[37,53]$ and a higher level of detection of problems on web pages and APPs, too. This coincides with studies carried out by [86] in Italy, where the application of new technologies in the sector is related to the only possible way to continue being competitive and to improve sustainability. In addition, in researches led by [25], it can be observed that the increase in the farm income is associated with the capacity of innovation.

In relation to the intensification of farms, it has also been observed that the larger the farm, the more investment in precision technologies (such as milking rooms, milking robots, automatic food-approaching systems, automatic cleaning systems or electronic animal-identification systems, among others). This result coincides with those obtained in studies directed by [55] on 199 farmers in Austria, where they also observed the relation existing between the size of the farm and the adoption of precision technologies. While it is true that in researches performed by [27] in England and Wales, it can be seen how the dairy industry tendencies have brought about two different types of farms (an extensive one, with less milk performance per animal and with more labour force; and an intensive one, with more performance per animal and less labour force), in our studies, a clear tendency has been observed towards intensive livestock farming, for, based on one of our main premises, 'milk litres per cow', it becomes fairly complicated to reach the market tendencies through an extensive manner.

Concerning the use of applications, all of the interviewed farmers knew, to a greater or lesser extent, how to use some smartphone APPs. As shown in the results, Whatsapp was one of their favourite APPs, their choice reflecting its perceived ease of use and its versatility, allowing them to communicate quickly with any user (suppliers, veterinarians, etc.) through text messages, documents and pictures. The importance of this application is highlighted in studies carried out by [15] in Chile, where users claimed that they felt left behind by not using applications such as this; also in addition, other research done by [87] in the Netherlands shows the importance of this application, arguing points closely related to the results of our studies, such as quick and direct communication. In our research, we have also identified the great importance of the use of email, of which the users highlighted its formal character as a legal evidence when performing operations; without forgetting that a smaller part of the users also mentioned the importance of farm-control APPs due to the fact that, thanks to them, they could leave the farm confidently since they would be notified of any existing disturbance on the farm by the APP. In spite of the fact that only a small group chose these applications of farm control as their favourites, $82 \%$ had used them on a daily basis.

The aforementioned results are closely related to those obtained by [77] in their studies performed in Germany on dairy farmers, where it was observed that $93 \%$ of the farmers used smartphones and $61 \%$ used applications of farm control. In this study, it has also been observed how the surveyed people assessed those functions related to the observation of animal health, farm control, reproductive control and farm data collection as the most useful ones. A fairly similar result was obtained in our survey when we asked them if they considered that an application by the public administration would be useful, where $97 \%$ assessed it as very useful and $91 \%$ claimed that the integration of procedures would be necessary, arguing the great usefulness of being able to have available, in a single application, all the data concerning their animals, from birth and death registration, to entries and exits of animals, produced litres control and oestrus control, among others. 


\section{Conclusions}

The dairy sector, in particular the Galician one, is currently immersed in a new tendency towards a reduction in the number of farms and an increase in the production per animal. Hand in hand with this new reality go the ICT, which are considered a method to obtain the objectives both at the market and government level. In terms of public administration, it is worth mentioning the change of paradigm which it has suffered due to the transformation of methods employed for the resolution of procedures, which have changed from in-person to telematic affairs. This situation, as shown by the methodology employed for data collection, generates lack of knowledge and uncertainties in many occasions on the farmers' part when it comes to carrying out the aforementioned procedures, which has translated into calls to telephone customer service, trips to regional agrarian offices or outsourcing authorised entities.

The results obtained have given an answer to the objectives set for this research, showing the dairy famers' current situation concerning the fulfilment of administrative procedures, and bringing us closer to the technological reality in which they live, as well as allowing us to know their aptitudes with new technologies.

As has been observed, there are different user profiles depending on different factors, such as age, the size of the farm or instructions. In spite of the fact that the majority of the interviewees have proved to know and use the ICT to a greater or lesser extent, there are still problems when carrying out procedures. These are related to poor connections, difficulties in understanding the procedures, web applications which do not meet the users' necessities or the lack of knowledge and use of the new technologies. In future research, we will try to give an answer to those users with difficulties when fulfilling procedures, delving into affairs related to interfaces or the tools employed nowadays to solve them.

Author Contributions: Conceptualization, A.V.-L. and M.M.-P.; methodology A.V.-L. and M.M.-P.; validation A.V.-L. and M.M.-P.; formal analysis A.V.-L. and M.M.-P.; research A.V.-L. and M.M.-P.; data curation A.V.-L. and M.M.-P.; writing-original draft preparation A.V.-L. and M.M.-P.; writingreview and editing A.V.-L. and M.M.-P. All authors have read and agreed to the published version of the manuscript.

Funding: We would like to thank the Galician Government (Xunta de Galicia) for their financial support with a grant for Competitive Reference Groups ED431C-2021-27.

Institutional Review Board Statement: Not applicable.

Informed Consent Statement: Informed consent was obtained from all subjects involved in the study.

Data Availability Statement: All data were extracted from public sources, mostly from scientific papers.

Acknowledgments: The authors would like to express their gratitude to Xoel Rodríguez Rodríguez for his work translating this paper.

Conflicts of Interest: The authors declare no conflict of interest.

\section{References}

1. European Commission. Europe 2020: A Strategy for Smart, Sustainable and Inclusive Growth; European Commission: Brussels, Belgium, 2010. Available online: https: / / ec.europa.eu/eu2020/pdf/COMPLET\%20EN\%20BARROSO\%20\%20\%20007\%20-\% 20Europe\%202020\%20-\%20EN\%20version.pdf (accessed on 20 July 2021).

2. Costa, C.; Murphy, M. EU digital media policies and education: The challenge of a digital agenda for Europe. In Education and Public Policy in the European Union; Palgrave Macmillan: Cham, Switzerland, 2019; pp. 149-164.

3. Tucci, C.L.; Poulin, D. Introduction to the special issue on electronic government: Investment in communities, firms, technologies and infrastructure. Electron. Commer. Res. 2015, 15, 301-302. [CrossRef]

4. Twizeyimana, J.D.; Andersson, A. The public value of E-Government-A literature review. Gov. Inf. Q. 2019, 36, 167-178. [CrossRef]

5. Mergel, I.; Edelmann, N.; Haug, N. Defining digital transformation: Results from expert interviews. Gov. Inf. Q. 2019, $36,101385$. [CrossRef] 
6. Law 39/2015, of October 1, on the Common Administrative Procedure of Public Administrations. Boletín Oficial del Estado, 2 October 2015, 89343 to 89410. Available online: https://www.boe.es/boe/dias/2015/10/02/pdfs/BOE-A-2015-10565.pdf (accessed on 4 July 2021).

7. Salemink, K. Digital margins: Social and digital exclusion of Gypsy-Travelers in the Netherlands. Environ. Plan. A Econ. Space 2016, 48, 1170-1187. [CrossRef]

8. Salemink, K.; Strijker, D. Rural broadband initiatives in the Netherlands as a training ground for neo-endogenous development. Local Econ. J. Local Econ. Policy Unit 2016, 31, 778-794. [CrossRef]

9. Inkinen, T.; Merisalo, M.; Makkonen, T. Variations in the adoption and willingness to use e-services in three differentiated urban areas. Eur. Plan. Stud. 2018, 26, 950-968. [CrossRef]

10. Townsend, L.; Wallace, C.; Fairhurst, G. 'Stuck out here': The critical role of broadband for remote rural places. Scott. Geogr. J. 2015, 131, 171-180. [CrossRef]

11. Vázquez-López, A.; Barrasa-Rioja, M.; Marey-Perez, M. ICT in Rural Areas. ICT in Rural Areas from the Perspective of Dairy Farming: A Systematic Review. Future Int. 2021, 13, 99. [CrossRef]

12. Vázquez-López, A.; Barrasa-Rioja, M.; Marey-Perez, M. How Do Dairy Farmers Communicate with the Government? A Case Study Northwest Spain. 2021; unpublished data.

13. Correa, T.; Pavez, I. Digital Inclusion in Rural Areas: A Qualitative Exploration of Challenges Faced by People From Isolated Communities. J. Comput. Commun. 2016, 21, 247-263. [CrossRef]

14. Salemink, K.; Strijker, D.; Bosworth, G. Rural development in the digital age: A systematic literature review on unequal ICT availability, adoption, and use in rural areas. J. Rural Stud. 2017, 54, 360-371. [CrossRef]

15. Pavez, I.; Correa, T.; Contreras, J. Meanings of (dis)connection: Exploring non-users in isolated rural communities with internet access infrastructure. Poetics 2017, 63, 11-21. [CrossRef]

16. Roberts, E.; Anderson, B.A.; Skerratt, S.; Farrington, J. A review of the rural-digital policy agenda from a community resilience perspective. J. Rural Stud. 2017, 54, 372-385. [CrossRef]

17. Freeman, J.; Park, S.; Middleton, C. Technological literacy and interrupted internet access. Inf. Commun. Soc. 2019, 23, 1947-1964. [CrossRef]

18. Magnusson, D.; Hermelin, B. ICT development from the perspective of connectivity and inclusion-the operation of a local digital agenda in Sweden. Nor. Geogr. Tidsskr. Nor. J. Geogr. 2019, 73, 81-95. [CrossRef]

19. Stocker, V.; Whalley, J. Who replies to consultations, and what do they say? The case of broadband universal service in the UK. Telecommun. Policy 2019, 43, 101823. [CrossRef]

20. Tiwari, S.; Lane, M.; Alam, K. Do social networking sites build and maintain social capital online in rural communities? J. Rural Stud. 2019, 66, 1-10. [CrossRef]

21. Young, J.C. Rural digital geographies and new landscapes of social resilience. J. Rural Stud. 2019, 70, 66-74. [CrossRef]

22. Hardy, J.; Dailey, D.; Wyche, S.; Su, N.M. Rural computing: Beyond access and infrastructure. In Proceedings of the 2018 ACM Conference on Computer Supported Cooperative Work and Social Computing, New York, NY, USA, 3-7 November 2018; pp. 463-470.

23. Price, L.; Shutt, J.; Sellick, J. Supporting rural Small and Medium-sized Enterprises to take up broadband-enabled technology: What works? Local Econ. J. Local Econ. Policy Unit 2018, 33, 515-536. [CrossRef]

24. Park, S.; Freeman, J.; Middleton, C. Intersections between connectivity and digital inclusion in rural communities. Commun. Res. Pract. 2019, 5, 139-155. [CrossRef]

25. Läpple, D.; Thorne, F. The role of innovation in farm economic sustainability: Generalised propensity score evidence from Irish dairy farms. J. Agric. Econ. 2019, 70, 178-197. [CrossRef]

26. Caja, G.; Castro-Costa, A.; Knight, C.H. Engineering to support wellbeing of dairy animals. J. Dairy Res. 2016, 83, 136-147. [CrossRef]

27. Gonzalez-Mejia, A.; Styles, D.; Wilson, P.; Gibbons, J. Metrics and methods for characterizing dairy farm intensification using farm survey data. PLoS ONE 2018, 13, e0195286. [CrossRef] [PubMed]

28. Kühl, S.; Flach, L.; Gauly, M. Economic assessment of small-scale mountain dairy farms in South Tyrol depending on feed intake and breed. Ital. J. Anim. Sci. 2019, 19, 41-50. [CrossRef]

29. Methorst, R.; Roep, D.; Verhees, F.; Verstegen, J. Drivers for differences in dairy farmers' perceptions of farm development strategies in an area with nature and landscape as protected public goods. Local Econ. 2016, 31, 554-571. [CrossRef]

30. Salmon, G.; Teufel, N.; Baltenweck, I.; van Wijk, M.; Claessens, L.; Marshall, K. Trade-offs in livestock development at farm level: Different actors with different objectives. Glob. Food Secur. 2018, 17, 103-112. [CrossRef]

31. Clay, N.; Garnett, T.; Lorimer, J. Dairy intensification: Drivers, impacts and alternatives. Ambio 2020, 49, 35-48. [CrossRef] [PubMed]

32. Wolfert, S.; Ge, L.; Verdouw, C.; Bogaardt, M.J. Big data in smart farming-A review. Agric. Syst. 2017, 153, 69-80. [CrossRef]

33. Bronson, K. Smart Farming: Including Rights Holders for Responsible Agricultural Innovation. Technol. Innov. Manag. Rev. 2018, 8,7-14. [CrossRef]

34. Janc, K.; Czapiewski, K.; Wójcik, M. In the starting blocks for smart agriculture: The internet as a source of knowledge in transitional agriculture. NJAS Wagening. J. Life Sci. 2019, 90-91, 100309. [CrossRef] 
35. Walter, A.; Finger, R.; Huber, R.; Buchmann, N. Opinion: Smart farming is key to developing sustainable agriculture. Proc. Natl. Acad. Sci. USA 2017, 114, 6148-6150. [CrossRef]

36. Tzounis, A.; Katsoulas, N.; Bartzanas, T.; Kittas, C. Internet of Things in agriculture, recent advances and future challenges. Biosyst. Eng. 2017, 164, 31-48. [CrossRef]

37. Diez-Olivan, A.; Del Ser, J.; Galar, D.; Sierra, B. Data fusion and machine learning for industrial prognosis: Trends and perspectives towards Industry 4.0. Inf. Fusion 2019, 50, 92-111. [CrossRef]

38. Zamora-Izquierdo, M.A.; Santa, J.; Martínez, J.A.; Martínez, V.; Skarmeta, A.F. Smart farming IoT platform based on edge and cloud computing. Biosyst. Eng. 2019, 177, 4-17. [CrossRef]

39. Davidson, C. The Green New Deal: What Makes It Necessary, What It Is, and How We Can Get It. Perspect. Glob. Dev. Technol. 2020, 19, 159-165. [CrossRef]

40. Romera, A.; Bos, A.; Neal, M.; Eastwood, C.; Chapman, D.; McWilliam, W.; Royds, D.; O'Connor, C.; Brookes, R.; Connolly, J.; et al. Designing future dairy systems for New Zealand using reflexive interactive design. Agric. Syst. 2020, 181, 102818. [CrossRef]

41. Berton, M.; Bittante, G.; Zendri, F.; Ramanzin, M.; Schiavon, S.; Sturaro, E. Environmental impact and efficiency of use of resources of different mountain dairy farming systems. Agric. Syst. 2020, 181, 102806. [CrossRef]

42. Philip, L.; Cottrill, C.; Farrington, J.; Williams, F.; Ashmore, F. The digital divide: Patterns, policy and scenarios for connecting the 'final few'in rural communities across Great Britain. J. Rural Stud. 2017, 54, 386-398. [CrossRef]

43. Sawalha, S.; Al Jamal, M.; Abu Shanab, E. The influence of utilising Facebook on e-government adoption. Electron. Gov. Int. J. 2019, 15. [CrossRef]

44. Naranjo-Zolotov, M.; Oliveira, T.; Casteleyn, S.; Irani, Z. Continuous usage of e-participation: The role of the sense of virtual community. Gov. Inf. Q. 2019, 36, 536-545. [CrossRef]

45. Faaeq, M.; Al Swidi, A.K. How Robust is the UTAUT Theory in Explaining the Usage Intention of E-Government Services in an Unstable Security Context?: A Study in Iraq. Electron. Gov. Int. J. 2019, 15. [CrossRef]

46. Zhang, B.; Zhu, Y. Comparing attitudes towards adoption of e-government between urban users and rural users: An empirical study in Chongqing municipality, China. Behav. Inf. Technol. 2020, 1-15. [CrossRef]

47. Demirdoven, B.; Cubuk, E.B.S.; Karkin, N. Establishing relational trust in e-Participation: A systematic literature review to propose a model. In Proceedings of the 13th International Conference on Theory and Practice of Electronic Governance, Athens, Greece, 23-25 September 2020; pp. 341-348.

48. Mensah, I.K.; Adams, S. A Comparative Analysis of the Impact of Political Trust on the Adoption of E-Government Services. Int. J. Public Adm. 2019, 43, 682-696. [CrossRef]

49. Mensah, I.K.; Zeng, G.; Luo, C. The Effect of Gender, Age, and Education on the Adoption of Mobile Government Services. Int. J. Semant. Web Inf. Syst. 2020, 16, 35-52. [CrossRef]

50. Mensah, I.K.; Zeng, G.; Luo, C. E-Government Services Adoption: An Extension of the Unified Model of Electronic Government Adoption. SAGE Open 2020, 10, 2158244020933593. [CrossRef]

51. Gulatee, Y.; Yuan, Q.; Gasco-Hernandez, M.; Gil-Garcia, J.R.; Sutherland-Mitzner, M.; Pardo, T.A. Technology adoption for emergency preparedness and response in rural areas: Identifying the main determinants. In Proceedings of the 13th International Conference on Theory and Practice of Electronic Governance, Athens, Greece, 23-25 September 2020; pp. 469-476.

52. Michels, M.; Bonke, V.; Musshoff, O. Understanding the adoption of smartphone apps in dairy herd management. J. Dairy Sci. 2019, 102, 9422-9434. [CrossRef]

53. Hennessy, T.; Laepple, D.; Moran, B. The Digital Divide in Farming: A Problem of Access or Engagement? Appl. Econ. Perspect. Policy 2016, 38, 474-491. [CrossRef]

54. Mulla, D.J. Twenty five years of remote sensing in precision agriculture: Key advances and remaining knowledge gaps. Biosyst. Eng. 2013, 114, 358-371. [CrossRef]

55. Gargiulo, J.I.; Eastwood, C.R.; Garcia, S.C.; Lyons, N.A. Dairy farmers with larger herd sizes adopt more precision dairy technologies. J. Dairy Sci. 2018, 101, 5466-5473. [CrossRef]

56. Weissensteiner, R.; Fürst-Waltl, B.; Gstöttinger, F.; Eder, H.; Janacek, R.; Koblmüller, M.; Mayerhofer, M.; Perner, J.; Schagerl, M.; Schoder, G.; et al. An online survey about data use in Austria's dairy farming-current status and development needs. Züchtungskunde 2018, 90, 96-111.

57. Pereira, A.; Carballo-Penela, A.; González-López, M.; Vence, X. A case study of servicizing in the farming-livestock sector: Organisational change and potential environmental improvement. J. Clean. Prod. 2016, 124, 84-93. [CrossRef]

58. López, E.T.; Leira, R.D.; Martínez, M.G.; Bugallo, P.M.B. Integrated environmental permit through Best Available Techniques: Evaluation of the dairy industry. J. Clean. Prod. 2017, 162, 512-528. [CrossRef]

59. Saavedra-Nieves, A.; Saavedra-Nieves, P. On systems of quotas from bankruptcy perspective: The sampling estimation of the random arrival rule. Eur. J. Oper. Res. 2020, 285, 655-669. [CrossRef]

60. Kulatunga, C.; Shalloo, L.; Donnelly, W.; Robson, E.; Ivanov, S. Opportunistic Wireless Networking for Smart Dairy Farming. IT Prof. 2017, 19, 16-23. [CrossRef]

61. O'Grady, M.J.; O'Hare, G.M. Modelling the smart farm. Inf. Process. Agric. 2017, 4, 179-187. [CrossRef]

62. Zambon, I.; Cecchini, M.; Egidi, G.; Saporito, M.G.; Colantoni, A. Revolution 4.0: Industry vs. agriculture in a future development for SMEs. Processes 2019, 7, 36. [CrossRef] 
63. Coble, K.H.; Mishra, A.K.; Ferrell, S.; Griffin, T. Big Data in Agriculture: A Challenge for the Future. Appl. Econ. Perspect. Policy 2018, 40, 79-96. [CrossRef]

64. Jakku, E.; Taylor, B.; Fleming, A.; Mason, C.; Fielke, S.; Thorburn, P.; Sounness, C. If they don't tell us what they do with it, why would we trust them?'Applying the multi-level perspective on socio-technical transitions to understand trust, transparency and benefit-sharing in Smart Farming and Big Data. In Proceedings of the 13th European International Farm Systems Association Symposium, Chania, Greece, 1-5 July 2018; pp. 1-5.

65. Jayaraman, P.P.; Yavari, A.; Georgakopoulos, D.; Morshed, A.; Zaslavsky, A. Internet of Things Platform for Smart Farming: Experiences and Lessons Learnt. Sensors 2016, 16, 1884. [CrossRef] [PubMed]

66. Eitzinger, A.; Cock, J.; Atzmanstorfer, K.; Binder, C.R.; Läderach, P.; Bonilla-Findji, O.; Bartling, M.; Mwongera, C.; Zurita, L.; Jarvis, A. GeoFarmer: A monitoring and feedback system for agricultural development projects. Comput. Electron. Agric. 2019, 158, 109-121. [CrossRef] [PubMed]

67. Pappa, I.; Illiopoulos, C.; Massouras, T. On Sustainability of a Dairy Sector in Crisis. Int. J. Food Syst. Dyn. 2019, 10, 130-150.

68. Castro, A.; Pereira, J.M.; Amiama, C.; Bueno, J. Typologies of Dairy Farms with Automatic Milking System in Northwest Spain and Farmers' Satisfaction. Ital. J. Anim. Sci. 2015, 14. [CrossRef]

69. Bugueiro, A.; Fouz, R.; Camino, F.; Yus, E.; Diéguez, F.J. Robot milking and relationship with culling rate in dairy cows. Animal 2019, 13, 1304-1310. [CrossRef] [PubMed]

70. Djamba, Y.K.; Neuman, W.L. Social Research Methods: Qualitative and Quantitative Approaches. Teach. Sociol. 2002, 30, 380. [CrossRef]

71. Butler, D.; Holloway, L. Technology and restructuring the social field of dairy farming: Hybrid capitals, 'stockmanship' and automatic milking systems. Sociol. Rural 2016, 56, 513-530. [CrossRef]

72. Verhees, F.; Malak-Rawlikowska, A.; Stalgiene, A.; Kuipers, A.; Klopčič, M. Dairy farmers' business strategies in Central and Eastern Europe based on evidence from Lithuania, Poland and Slovenia. Ital. J. Anim. Sci. 2018, 17, 755-766. [CrossRef]

73. O'Donoghue, C.; Heanue, K. The impact of formal agricultural education on farm level innovation and management practices. J. Technol. Transf. 2018, 43, 844-863. [CrossRef]

74. McKillop, J.; Heanue, K.; Kinsella, J. Are all young farmers the same? An exploratory analysis of on-farm innovation on dairy and drystock farms in the Republic of Ireland. J. Agric. Educ. Ext. 2018, 24, 137-151. [CrossRef]

75. Hyland, J.J.; Heanue, K.; McKillop, J.; Micha, E. Factors influencing dairy farmers' adoption of best management grazing practices. Land Use Policy 2018, 78, 562-571. [CrossRef]

76. Triste, L.; Debruyne, L.; Vandenabeele, J.; Marchand, F.; Lauwers, L. Communities of practice for knowledge co-creation on sustainable dairy farming: Features for value creation for farmers. Sustain. Sci. 2018, 13, 1427-1442. [CrossRef]

77. Michels, M.; Fecke, W.; Feil, J.-H.; Musshoff, O.; Pigisch, J.; Krone, S. Smartphone adoption and use in agriculture: Empirical evidence from Germany. Precis. Agric. 2019, 21, 403-425. [CrossRef]

78. Mead, R.; Curnow, R.N.; Hasted, A.M. Statistical Methods in Agriculture and Experimental Biology; Chapman and Hall/CRC: Boca Raton, FL, USA, 2017.

79. MacFarland, T.W.; Yates, J.M. Introduction to Nonparametric Statistics for the Biological Sciences Using R; Springer: Cham, Switzerland, 2016; pp. 103-132.

80. Shadbolt, N.M. Resilience, Risk and Entrepreneurship. Int. Food Agribus. Manag. Rev. 2016, 19, $33-52$.

81. Warf, B. Teaching Digital Divides. J. Geogr. 2018, 118, 77-87. [CrossRef]

82. Aerschot, L.V.; Rodousakis, N. The link between socio-economic background and Internet use: Barriers faced by low socioeconomic status groups and possible solutions. Innov. Eur. J. Soc. Sci. Res. 2008, 21, 317-351. [CrossRef]

83. Galindo-Pérez-De-Azpillaga, L.; Foronda-Robles, C. Digital governance and information technologies in local action groups (LAGs). Cogent Soc. Sci. 2018, 4. [CrossRef]

84. Jacob, D.W.; Fudzee, M.F.M.; Salamat, M.A.; Herawan, T. A review of the generic end-user adoption of e-government services. Int. Rev. Adm. Sci. 2019, 85, 799-818. [CrossRef]

85. Eastwood, C.R.; Rue, B.T.D.; Gray, D.I. Using a 'network of practice' approach to match grazing decision-support system design with farmer practice. Anim. Prod. Sci. 2017, 57, 1536-1542. [CrossRef]

86. Bucci, G.; Bentivoglio, D.; Finco, A. Factors affecting ICT adoption in agriculture: A case study in Italy. Calitatea 2019, 20, 122-129.

87. Townsend, L.; Wallace, C.; Fairhurst, G.; Anderson, A. Broadband and the creative industries in rural Scotland. J. Rural Stud. 2017, 54, 451-458. [CrossRef] 